Shivanthan Shanthikumar ORCID iD: 0000-0001-6000-3180

\title{
GENE MODIFIERS OF CYSTIC FIBROSIS LUNG DISEASE: A SYSTEMATIC REVIEW
}

\section{Authors;}

\section{Shivanthan Shanthikumar; MBBS}

a. Respiratory and Sleep Medicine, Royal Children's Hospital, Melbourne, Australia;

b. Respiratory Diseases, Murdoch Children's Research Institute, Melbourne, Australia; c. Department of Paediatrics, The University of Melbourne, Australia. Melanie N Neeland; PhD

d. Centre of Food and Allergy Research, Murdoch Children's Research Institute, Melbourne, Australia; c. Department of Paediatrics, The University of Melbourne, Australia.

\section{Richard Saffery; PhD}

e. Cancer \& Disease Epigenetics, Murdoch Children's Research Institute, Melbourne, Australia; c. Department of Paediatrics, The University of Melbourne, Australia.

\section{Sarath Ranganathan; PhD}

a. Respiratory and Sleep Medicine, Royal Children's Hospital, Melbourne, Australia;

b. Respiratory Diseases, Murdoch Children's Research Institute, Melbourne, Australia; c. Department of Paediatrics, The University of Melbourne, Australia.

\section{Corresponding Author;}

Shivanthan Shanthikumar

Email; shivanthan.shanthikumar@rch.org.au

Phone; +6139345 5818

Address; Respiratory and Sleep Medicine, Royal Children's Hospital; Parkville, VIC, 3052, AUSTRALIA

This is the author manuscript accepted for publication and undergone full peer review but has not been through the copyediting, typesetting, pagination and proofreading process, which may lead to differences between this version and the Version of Record. Please cite this article as doi: 10.1002/ppul.24366.

This article is protected by copyright. All rights reserved. 


\section{Keywords}
1. Cystic Fibrosis
2. Genes, Modifier
3. Epigenomics
4. Gene Expression

\section{ABSTRACT}

\section{Background}

Lung disease is the major source of morbidity and mortality in cystic fibrosis (CF), with large variability in severity between patients. Although accurate prediction of lung disease severity would be extremely useful, no robust methods exist. Twin and sibling studies have highlighted the importance of non-cystic fibrosis transmembrane conductance regulator (CFTR) genes in determining lung disease severity but how these impact on severity in CF remains unclear.

\section{Methods}

A systematic review was undertaken to answer the question "In patients with CF which non-CFTR genes modify the severity of lung disease?" The method for this systematic review was based upon the "Preferred Reporting Items for Systematic Reviews and Meta-Analyses (PRISMA)" statement, with a narrative synthesis of results planned.

\section{Results}

1168 articles were screened for inclusion, with 275 articles undergoing detailed assessment for inclusion. 140 articles were included. Early studies focused on This article is protected by copyright. All rights reserved. 
candidate genes, while more recent studies utilised genome-wide approaches and also examined epigenetic mechanisms, gene expression, and therapeutic response.

\section{Discussion}

A large body of evidence regarding non-CFTR gene modifiers of lung disease severity has been generated, examining a wide array of genes. Limitations to existing studies include heterogeneity in outcome measures used, limited replication and relative lack of clinical impact. Future work examining non-CFTR gene modifiers will have to overcome these limitations if gene modifiers are to have a meaningful role in the care of patients with CF.

\section{INTRODUCTION}

Lung disease is the major source of morbidity and mortality in cystic fibrosis (CF), however there is significant variability in severity between patients. ${ }^{1,2}$ Accurate prediction of severity would be extremely useful (see table 1), and the ability to stratify patients could potentially help to address 8 of the top 10 research priorities in CF recently determined by stakeholders. ${ }^{3}$ For example, one priority concerns effective ways of simplifying the treatment burden in patients with CF, and it would likely be easier to simplify the burden in patients predicted to have mild lung disease.

It was originally hypothesised that cystic fibrosis transmembrane conductance regulator (CFTR) mutation status could predict lung disease severity. However, multiple studies demonstrated that for the majority of disease causing mutations,

This article is protected by copyright. All rights reserved. 
this is not the case. ${ }^{1,2,4}$ Subsequently, it was hypothesised that the severity of pulmonary phenotype may be impacted by environmental or non-CFTR genetic factors. ${ }^{5}$ As early as 1990 the potential role of non-CFTR gene modifiers was proposed. ${ }^{6}$ Family and, in particular, twin studies are a well-established method for determining the relative contribution of genetic and environmental factors and two major twin and sibling studies conducted in CF both showed that non-CFTR genetic modifiers play a significant role in determining lung disease severity. ${ }^{7,8} 9$

Numerous studies have attempted to identify which genes affect CF lung disease severity and have been the subject of multiple expert reviews ${ }^{10-14}$ but to our knowledge no systematic reviews have been performed. The aim of this study was to systematically review the evidence for the effect of non-CFTR modifier genes on CF lung disease severity.

\section{METHODS}

The method for this systematic review was based upon the "Preferred Reporting Items for Systematic Reviews and Meta-Analyses (PRISMA)" statement ${ }^{15}$ and the review was registered with PROSPERO (CRD42017070836). ${ }^{16}$

\subsection{Research Question}

"In patients with CF which non-CFTR genes modify the severity of lung disease?"

This article is protected by copyright. All rights reserved. 


\subsection{Search Strategy}

Databases searched and search terms used are detailed in Appendix A. Searches were limited to the English language. Reference lists from identified articles were also searched for relevant articles.

\subsection{Study Selection}

Duplicate articles were removed. Titles and abstracts were reviewed and inclusion and exclusion criteria (see Table 2) were applied. For articles remaining after initial review, full text was obtained and re-reviewed for inclusion or exclusion. Where data were only available in abstract form they were included if they had been published in a peer-reviewed journal. Where full text articles were unable to be obtained, the corresponding author was contacted to provide a copy, and if this was not successful the article was excluded.

\subsection{Data Extraction}

Data, including gene name, study method, patient number, country, age, gender, CFTR genotype, lung disease outcome and results, were extracted into a template developed by the authors. Study method was classified as candidate vs. systemic, qualitative vs. quantitative, and linkage vs. association based on previously published definitions. ${ }^{17}$

This article is protected by copyright. All rights reserved. 


\subsection{Quality Assessment and Data Synthesis}

It was anticipated that the results of the search would not allow for a meta-analysis due to heterogeneity in terms of study population, genes investigated and lung disease outcomes used. As such, a narrative synthesis was planned. To assess the quality of included studies the Q-Genie tool, which is specifically designed to assess

the quality of genetic association studies, was used. ${ }^{18}$ Briefly, each paper is assessed based on 11 criteria. A 7 point Likert scale is used from poor (1) to excellent (7), and a score assigned for each criteria. The score from each criterion are then combined to give the overall score. The maximum score a paper can obtain is 77.

\section{RESULTS}

\subsection{Summary of Searches}

A PRISMA diagram summarising the results of the systematic review is shown in Figure 1. Reasons for exclusion of the papers where full text review was undertaken are detailed in Supplementary Table 1.

\subsection{Data Synthesis}

The data extracted from the 140 included papers are summarised in Supplementary Table 2, Supplementary Table 3, and Table 3. The results are briefly summarised below, with more detail regarding findings of individual studies and the body of evidence for each gene summarised found in Supplementary Table 2 and Supplementary Table 3 respectively.

This article is protected by copyright. All rights reserved. 


\subsubsection{Candidate Gene/Region Approach}

The initial studies of non-CFTR gene modifiers of CF disease severity focused on investigating candidate genes or regions involved in pathways implicated in the pathogenesis of CF lung disease. The majority of these studies used an association based methodology, whilst some used linkage or a combined approach (such as transmission disequilibrium testing) (see table 3 ). Whilst the majority of gene modifier studies have been candidate gene studies, the highest quality evidence has been derived from larger studies which used a genome wide approach. As such only the studies regarding selected genes are described. Summaries of all candidate gene studies are found in the attached tables.

\section{Transforming Growth Factor Beta 1 (TGF $\beta 1)$}

$T G F \beta 1$, was postulated to be a gene modifier due to its role in inflammation, fibrosis, and chloride transport ${ }^{19}$ is one of the most widely investigated gene modifiers, having been investigated by 15 different studies. ${ }^{20-34}$ These studies have examined 3 different sites, with codon 10 being of most interest. The studies have yielded conflicting results, but several studies including the large Gene Modifier Study ${ }^{21}$, have shown that the CC genotype is associated with more severe disease. The CC genotype is associated with increased TGF $\beta 1$ expression which could cause more severe disease due to increased inflammation and fibrosis. ${ }^{19}$ Studies have also demonstrated an interplay between tobacco smoke exposure and TGF $\beta 1$ in determining disease severity ${ }^{28}$, as well as interaction with other gene modifiers. ${ }^{24}$

This article is protected by copyright. All rights reserved. 
Mannose Binding Lectin (MBL)

$M B L$ is part of the innate immune response, and $M B L$ deficiency is associated with increased susceptibility to infection. ${ }^{35} \mathrm{MBL}$ has been extensively studied as a gene modifier, with a number of studies ${ }^{21,24,25,32,36-47}$ showing as hypothesised, a low MBL production genotype is associated with several measures of more severe lung disease such as higher infection rates, lower lung function, and lower survival. Of note the most robust study found no effect of $M B L^{21}$

Macrophage Migration Inhibitory Factor (MIF)

MIF is a proinflammatory mediator and in vitro models have shown that polymorphisms with five CATT repeats at the -794 promoter are associated with reduced gene expression. The number of CATT repeats at the -794 promoter of MIF was associated with lung disease severity in three studies, with as expected five CATT repeats being associated with milder lung disease in terms of lung function and PA infection. ${ }^{48-50}$ Due to poor coverage of the MIF gene in the some SNP microarray's this gene may not have been examined by CF GWAS studies.

\section{Glutathione S-Transferase Mu (GSTM1)}

Due to its role in protecting the lung from oxidative lung injury, GSTM1 has been investigated in 9 studies $^{21,34,51-57}$, and while some smaller studies ${ }^{51,52,54}$ showed a link between the null genotype and poorer outcomes, the largest study ${ }^{21}$ showed no effect. A possible explanation for this discrepancy is that the studies showing an effect used radiological and clinical score outcomes, whereas the large Gene Modifier study used FEV .

This article is protected by copyright. All rights reserved. 
CD14 is part of the innate immune response, and presence of a $\mathrm{C}$ allele at position 159 , is associated with reduced CD14 levels. CD14 genotype showed no effect on lung function in 2 studies. ${ }^{25,58}$ However, in a study using a very robust microbiological endpoint (annual bronchoalveolar lavage $(B A L)$ ) the low CD14 producing CC genotype at position -159 was associated with earlier acquisition of PA infection. ${ }^{59}$ There has been no attempt to replicate this finding.

Human haemochromatosis protein (HFE)

Higher iron levels the airway have been implicated in CF lung disease severity. ${ }^{60,61}$ HFE plays a crucial role in iron homeostasis, with mutations in HFE being associated with higher iron levels. HFE has been investigated in two separate Australian cohorts and showed that individuals with mutations had significantly lower lung function (absolute difference of $14.4 \%$ in $\mathrm{FEV}_{1}$ ) and a faster rate of decline in $\mathrm{FEV}_{1} .{ }^{62,63}$

Endothelin Receptor Type A (EDNRA)

EDNRA is a proinflammatory peptide and is also implicated in small airway constriction. One study investigated mutations in EDNRA across four different cohorts and found that at SNP rs5335, the CC genotype was associated with a $5 \%$ absolute reduction in lung function. ${ }^{64}$ Further in vivo experiments showed the CC genotype to be associated with increased EDNRA levels and hence a proinflammatory state. Methylation of EDNRA in blood but not nasal epithelial cells was subsequently shown to be inversely related to lung disease severity. ${ }^{34}$

This article is protected by copyright. All rights reserved. 
Carcinoembryonic antigen-related cell adhesion molecules (CEACAM)

CEACAM was identified as a modifier of lung disease severity in 2 separate studies 65,66

using the European Twins and Siblings cohort. These studies performed a linkage analysis whereby the distribution of alleles between mildly and severely affected sibling pairs and concordant and discordant siblings was compared to find gene modifiers.

Mucin

Due to the role of altered mucus in CF lung disease, a number of mucin (MUC) genes have been investigated. The international GWAS meta-analysis identified that a locus at 3q29 which contains MUC4 and MUC20 was associated with lung disease severity.

${ }^{67}$ A study of 762 patients found a relationship between MUC5AC variable number tandem repeat (VNTR) number and disease severity with the $6.4 \mathrm{~kb}$ VNTR being associated with more severe disease. ${ }^{68}$ Of note, all mucin genes have only been investigated in single studies with no attempted replication.

CFTR Vicinity

Several genes have been investigated as potential gene modifiers due to their proximity to CFTR. One study found that leptin 1 and 2 (LEP1, LEP2) were associated with increased disease severity. ${ }^{69}$ Another study analysed the region $7 q 31$ to $7 q$ tel and found a locus on 7q34 that showed differential onset of parental recombination and differential imprinting between mildly and severely affected sibling pairs. ${ }^{70}$

This article is protected by copyright. All rights reserved. 
However, both studies used composite measure of severity, which encompassed both respiratory and nutritional parameters. The authors of both studies hypothesised that the effect was most likely via an influence on nutrition.

\subsubsection{Systematic Genome Wide Approach}

As technology has evolved genome-wide searches, rather than targeted approaches, have become more common. Genome wide searches examine either the entire exome (the part of the genome which is responsible for coding proteins) via whole exome sequencing, or all SNPs via GWAS.

\section{Whole Exome Sequencing}

Two studies ${ }^{71,72}$ using whole exome sequencing identified genes that modify the risk of PA infection. Mutations in dynactin subunit 4 (DCTN4) and transmembrane channel-like protein 6 (TMC6) were associated with early onset of PA infection and a caveolin 2 (CAV2) variant was shown to be protective. These studies also showed an effect of TMC6 and CAV2 on lung function, with variants associated with earlier PA acquisition being associated with lower $\mathrm{FEV}_{1}$. One study attempted to replicate the findings with regards to DCTN4 and found it only affected risk of PA infection in a subgroup of males who had two class 2 CFTR mutations. ${ }^{73}$

GWAS

Three GWAS studies ${ }^{67,74,75}$ have been published to date, one of which pooled GWAS results from North America and France to perform a meta-analysis. ${ }^{67}$ A major strength of these GWAS studies when compared to previous candidate gene studies

This article is protected by copyright. All rights reserved. 
is the significantly larger number of subjects involved. For example, the GWAS metaanalysis included data from SNP microarrays from 6,365 patients, as compared to the largest candidate gene study which involved an initial cohort of 808 patients, with replication in 498 patients. This strength is reflected in the GWAS studies having the highest Q-Genie scores. The GWAS meta-analysis used $\mathrm{FEV}_{1}$ to measure lung disease severity. Five loci that were associated with lung disease severity were identified;

1. Chromosome 3q29, which contains MUC4 and MUC20, however no subsequent studies have investigated this region or the hypothesised genes.

2. Chromosome $5 \mathrm{p} 15.3$ contains solute carrier family 9A3 (SLC9A3), a gene which was also shown in 3 other studies ${ }^{33,76,77}$ to associate with lung disease severity.

3. Chromosome $6 \mathrm{p} 21.3$, contains HLA Class II which was shown in other studies $^{67,78,79}$ to associate with lung disease severity as measured by lung function and PA infection.

4. Chromosome Xq22-q23 contains angiotensin II receptor type 2 (AGTR2) and solute carrier family 6A14 (SLC6A14). No other studies have investigated AGTR2. SLC6A14 appeared to associate with both lung function and risk of PA infection in a large Canadian study. ${ }^{76}$

5. Chromosome 11p12-p13 contains ETS homologous factor (EHF) and together with $A P I P$, identified by a previous $\mathrm{GWAS}^{74}$, was included in the meta-analysis. A subsequent study used targeted resequencing of this area a

This article is protected by copyright. All rights reserved. 
group of 377 patients, and identified multiple SNPs associated with lung disease severity. ${ }^{80}$

While a number of the genes of interest in the five identified loci have not been further investigated and hence replicated, the GWAS meta-analysis did include analysis (via forest plots and Cochran's $Q$ test) where the patients were analysed in 13 sub populations (based on original cohort and SNP microarray platform used) to assess for heterogeneity. Using Cochran's Q test only the chromosome 3q29 loci showed evidence of heterogeneity and using a forest plot most of the subpopulations showed a significant effect of $3 q 29$. This analysis serves as a form of internal replication showing that the 5 loci of interest were still significant even when results were analysed in the 13 subpopulations.

A previous $\mathrm{GWAS}^{74}$ used linkage analysis to identify $20 \mathrm{q} 13.2$ as a modifier locus in a subset of 486 sibling pairs. Linkage analysis uses different methodology to that used in traditional GWAS analysis so the meta-analysis could not replicate this finding.

A separate publication used a novel analysis technique on data from GWAS performed in Canadian and French cohorts to analyse a set of genes which affect apical plasma membrane epithelia. ${ }^{77}$ This identified SLC9A3 (which had already been identified by the international GWAS), SLC9A3R2 and EZR as modifying lung disease severity. To date, no attempts at replicating the findings regarding SLC9A3R2 and EZR have been made.

This article is protected by copyright. All rights reserved. 


\subsubsection{Epigenetic}

Epigenetics refers to the phenomenon of heritable changes in gene expression that do not involve changes to the underlying DNA sequence. ${ }^{81}$ The most commonly investigated epigenetic mechanism is DNA methylation and four studies have investigated this. Ideozu et $a I^{82}$ analysed methylation at $A B C C 1-5$ and found no relationship between DNA methylation and disease severity. Magalhaes et $a l^{34}$ analysed DNA methylation of 13 candidate genes, in blood and nasal epithelial cells in a group of 48 patients, with a replication cohort of 30 . They found heme oxygenase 1 (HMOX1), EDNRA, and GSTM3 DNA methylation were associated with lung disease severity. Another epigenetic mechanism is imprinting, where one copy of a gene is silenced depending on which parent it was inherited from. Two separate studies from the European Twins and Siblings studies have hypothesised a relationship between imprinting of $7 q 34$ and disease severity. ${ }^{69,70}$

\subsubsection{Gene Expression}

There has been a recent increase in studies examining gene expression and CF lung disease severity. Two studies examined the effect of $A B C C 1$ gene expression, with Hurbain et $a l^{83}$ finding that low expression in nasal epithelial cells was associated with more severe clinical disease scores. However, a subsequent study ${ }^{82}$ did not find a relationship. Kelly et $a l^{84}$ identified that increased $A 20$ gene expression in nasal epithelial cells was associated with milder lung disease. Magalhaes et $\left.a\right|^{34}$ investigated gene expression of 13 candidate genes in blood and found no effect. Only one study examined genome-wide expression in nasal epithelial cells and

This article is protected by copyright. All rights reserved. 
identified genes related to oxidoreductase activity, the ubiquitin cycle and lipid metabolism to be associated with lung disease severity. ${ }^{85} \mathrm{~A}$ subsequent study, which examined gene expression in blood, identified gene pathways involved in HLA Class I, Phe508del processing and endoplasmic reticulum stress response to be associated with lung disease severity. ${ }^{79}$ In particular, lysophosphatidic acid receptor 6 (LPAR6) was found to be more highly expressed in those with severe lung disease.

\subsubsection{Theratype}

A theratype refers to factors which predict a patient's response to a treatment, and in CF there is scope to move beyond the existing focus on theratypes related to CFTR genotype. ${ }^{86}$ Several studies have examined gene modifiers of therapeutic response. Four studies ${ }^{87-90}$ examined whether polymorphisms of $\beta-2$ Adrenergic Receptor 2 (ADRB2), which is involved in bronchoconstriction, would affect whether patients responded to inhaled bronchodilator, and found there was no significant relationship. In a more recent, and highly relevant study, Strug et $a l^{91}$ examined the effect of gene modifier SLC26A9 (an alternate chloride channel identified via the GWAS meta-analysis) on the response to treatment with the CFTR modulator ivacaftor. They studied 24 Canadian patients with at least one gating mutation and measured $\mathrm{FEV}_{1}$ before and after treatment with ivacaftor. They genotyped patients at the SNP rs7512462, and found that for each C allele (as compared to T) there was a 9.8\% improvement in $\mathrm{FEV}_{1}$ response to ivacaftor.

This article is protected by copyright. All rights reserved. 


\section{DISCUSSION}

A significant body of evidence has been generated regarding potential modifiers of

CF lung disease severity. The wide array of genes that has been studied is in keeping with the numerous mechanisms implicated in the pathogenesis of CF lung disease. A key strength of the literature is that subjects from 27 different countries have been studied, and thus, a wide cross-section of the CF population is represented. This is countered by the majority of subjects, especially in genome wide studies, being from North America and Western Europe. There are, however, significant limitations within the evidence including variability in outcome measures, lack of replication, and limited data on subsequent clinical impact.

One issue limiting the comparability of papers is the large variability in outcome measures used. Fifty-three different outcome measures were used, with the most common measure being $\mathrm{FEV}_{1}$. For $\mathrm{FEV}_{1}$ at least 15 different reference equations were used, and often the selection and timing of $\mathrm{FEV}_{1}$ measurement was unclear. This limited the comparison of genome wide studies with each other and candidate gene studies. In the adult population one way to overcome this is for all studies to use KNORMA, the FEV 1 measure developed by the international GWAS consortium. A limitation of this approach is that it would not be applicable to children too young to perform spirometry, ${ }^{14}$ and given there are differences in lung disease severity observed in the first years of life, there remains great interest in gene modifier studies in this age group. In fact, a National Heart Lung Blood Institute workshop in primary prevention of chronic lung disease in CF called for identification of gene modifiers that affect lung disease severity in early life. ${ }^{92}$ Studies involving children This article is protected by copyright. All rights reserved. 
should use the most robust markers of lung disease severity in this age group, but they have been rarely used in gene modifier studies to date. Only two papers ${ }^{93,94}$ used the most sensitive measure of lung function (lung clearance index - LCl), ${ }^{959697}$ and one paper ${ }^{59}$ the most sensitive measure of lower respiratory infection (BAL). ${ }^{98}$ Computed Tomography (CT) scan results were used more widely, however not in younger age groups where they are very sensitive markers of lung disease severity. 99100

While over 100 individual genes have been investigated as potential gene modifiers, the majority of genes (76) have only been investigated in a single study. In order for any genotype-phenotype relationship to be thoroughly established, replication is key. ${ }^{17}$ However, for 48 genes where a relationship was identified there has as yet been no attempt at replication. This is more relevant for genes identified in candidate gene studies than for those identified in GWAS, as the GWAS metaanalysis including over 6000 patients used statistical tests of heterogeneity to replicate the findings in the subpopulations of patients included in the meta-analysis.

A relative limitation of evidence generated by studies investigating gene modifiers of CF is the limited clinical impact. The primary aim of gene modifier studies has been to identify therapeutic targets. Gene modifier studies in CF have identified some therapeutic targets. ${ }^{101}$ To date no clinical interventions have resulted, however, early trials are underway which will hopefully result in efficacious new treatments. ${ }^{101}$ Another potential application of identifying gene modifiers, that has not been the primary aim, but perhaps represents a missed opportunity, is using them to stratify patients into different risk categories (i.e mild lung disease, severe lung disease).

This article is protected by copyright. All rights reserved. 
These risk categories could in turn influence clinical management. Using gene modifier genes to stratify patient risk and inform clinical management is well established in oncology and has led to improved outcomes. ${ }^{102}$ To our knowledge, no CF centres use modifier genes to stratify patients and modify treatment. Utilising modifier genes in risk stratification would be a step towards a more personalised approach to treatment. Identification of gene modifiers which influence magnitude of response to treatments would also represent a potential clinical application. The discovery that SLC26A9 modified the magnitude of response to ivacaftor is an example of this. ${ }^{91}$ This has subsequently been replicated in a further recent study. ${ }^{103}$ Much more comprehensive validation is needed however before this discovery could be used in routine clinical practice. As more treatments are developed that ameliorate the basic CFTR defect, permitting multiple treatment options for patients with the same genotype, being able to predict which treatment will be of most benefit to the individual patient will be crucial and gene modifiers may be of use when determining this.

The strength of this systematic review is the broad search strategy and methodology which followed best practice guidelines. ${ }^{104}$ The authors feel that compared to the multiple expert reviews in the area, this present an unbiased and comprehensive review of the published literature. A limitation of the systematic review is the exclusion of animal studies and studies which purely examine in vitro gene expression (with no correlation to clinical outcomes). These studies interrogate potential mechanisms by which gene modifiers exert an effect and hence are very important, however given the already large size of the body of evidence to be

This article is protected by copyright. All rights reserved. 
reviewed, it was beyond the scope to include them. Another relative limitation is that the broad search strategy has led to the inclusion of a large number of articles, which means that each individual article is perhaps interrogated less than in the expert reviews which have less included articles.

Studies investigating gene modifiers continue to be published ${ }^{105,106}$ and moving forward, in order to aid robust discovery of genetic modifiers of disease, it would be ideal if future studies utilised gold standard measures of lung disease severity. In adult patients that might be universal use of KNORMA, and in children that could be a combination of $\mathrm{CT}, \mathrm{BAL}$ and $\mathrm{LCl}$. Whilst such testing may seem invasive, they are already being conducted regularly in cohorts such as AREST CF ${ }^{107}$ and the Toronto Sick Kids CF Cohort. ${ }^{108}$ Using insensitive measures of lung disease may result in inaccurate assessment of the contribution of gene-modifiers to lung disease severity. Moving forward, a challenge in phenotyping lung disease severity will be accounting for the effect of CFTR modulating therapies, given differences in lung disease severity may be related to eligibility and access to these therapies rather than true differences in lung disease severity. The magnitude of response to these treatments may represent an important phenotype worthy of further studies, as already highlighted in the studies examining response to ivacaftor. ${ }^{91,103}$ Any significant findings should then be replicated in separate cohorts using similar end points. For future work examining DNA methylation and gene expression, it will be important that initial gene discovery is based on samples from biologically relevant tissue (BAL, nasal epithelial cells) with subsequent replication in more easily obtained samples such as blood. ${ }^{81}$ Once genetic modifiers have been validated, the next step will be to This article is protected by copyright. All rights reserved. 
assess whether they can be used in clinical management of patients, with those associated with increased risk of more severe disease facilitating more aggressive intervention, and those associated with mild disease opportuning a reduced treatment burden. In this way, genetic modifiers of CF lung disease could inform more personalised and precise care for patients with CF.

\section{ACKNOWLEDGEMENTS}

The authors would like to thank Poh Chua for her invaluable assistance with developing and refining the search strategy.

\section{FUNDING}

Dr Shivanthan Shanthikumar was supported by the Thoracic Society of Australia and New Zealand Paediatric Cystic Fibrosis Fellowship. There are no conflicts of interest to declare.

\section{REFERENCES}

1. Kerem E, Corey M, Kerem BS, Rommens J, Markiewicz D, Levison H, Tsui LC, Durie $P$. The relation between genotype and phenotype in cystic fibrosis-analysis of the most common mutation (delta F508). N Engl J Med 1990;323(22):1517-22.

2. Cystic Fibrosis Genotype-Phenotype Consortium. Correlation between genotype and phenotype in patients with cystic fibrosis. N Engl J Med 1993;329(18):1308-13.

3. Rowbotham NJ, Smith S, Leighton PA, Rayner OC, Gathercole K, Elliott ZC, Nash EF, Daniels T, Duff AJA, Collins S and others. The top 10 research priorities in cystic fibrosis developed by a partnership between people with CF and healthcare providers. Thorax 2017.

This article is protected by copyright. All rights reserved. 
4. Koch C, Cuppens H, Rainisio M, Madessani U, Harms H, Hodson M, Mastella G, Navarro J, Strandvik B, McKenzie S. European Epidemiologic Registry of Cystic Fibrosis (ERCF): comparison of major disease manifestations between patients with different classes of mutations. Pediatr Pulmonol 2001;31(1):112.

5. Cutting GR. Cystic fibrosis genetics: from molecular understanding to clinical application. Nature Reviews Genetics 2015;16(1):45-56.

6. Santis G, Osborne L, Knight RA, Hodson ME. Independent genetic determinants of pancreatic and pulmonary status in cystic fibrosis. Lancet 1990;336(8723):1081-1084.

7. Collaco JM, Blackman SM, McGready J, Naughton KM, Cutting GR. Quantification of the relative contribution of environmental and genetic factors to variation in cystic fibrosis lung function. J Pediatr 2010;157(5):8027.e1-3.

8. Vanscoy LL, Blackman SM, Collaco JM, Bowers A, Lai T, Naughton K, Algire M, McWilliams R, Beck S, Hoover-Fong J and others. Heritability of lung disease severity in cystic fibrosis. Am J Respir Crit Care Med 2007;175(10):1036-43.

9. Mekus F, Ballmann M, Bronsveld I, Bijman J, Veeze H, Tummler B. Categories of deltaF508 homozygous cystic fibrosis twin and sibling pairs with distinct phenotypic characteristics. Twin Res 2000;3(4):277-93.

10. Weiler CA, Drumm ML. Genetic influences on cystic fibrosis lung disease severity. Frontiers in Pharmacology 2013;4 APR (no pagination)(Article 40).

11. Cutting GR. Modifier genes in Mendelian disorders: the example of cystic fibrosis. Annals of the New York Academy of Sciences 2010;1214:57-69.

12. Guillot L, Beucher J, Tabary O, Le Rouzic P, Clement A, Corvol H. Lung disease modifier genes in cystic fibrosis. International Journal of Biochemistry \& Cell Biology 2014;52:83-93.

13. Drumm ML, Ziady AG, Davis PB. Genetic variation and clinical heterogeneity in cystic fibrosis. Annual Review of Pathology: Mechanisms of Disease 2012;7:267-282.

14. O'Neal WK, Knowles MR. Cystic Fibrosis Disease Modifiers: Complex Genetics Defines the Phenotypic Diversity in a Monogenic Disease. Annu Rev Genomics Hum Genet 2018;19:201-222.

15. Moher D, Liberati A, Tetzlaff J, Altman DG. Preferred reporting items for systematic reviews and meta-analyses: the PRISMA statement. BMJ 2009;339.

This article is protected by copyright. All rights reserved. 
16. National Institute for Health Research. 2017 PROSPERO.

<https://www.crd.york.ac.uk/prospero/display_record.php?RecordID=70836>.

17. Genin E, Feingold J, Clerget-Darpoux F. Identifying modifier genes of monogenic disease: strategies and difficulties. Hum Genet 2008;124(4):35768.

18. Sohani ZN, Meyre D, de Souza RJ, Joseph PG, Gandhi M, Dennis BB, Norman $G$, Anand SS. Assessing the quality of published genetic association studies in meta-analyses: the quality of genetic studies (Q-Genie) tool. BMC Genetics 2015;16(1):50.

19. Kramer EL, Clancy JP. TGFbeta as a therapeutic target in cystic fibrosis. Expert Opin Ther Targets 2018;22(2):177-189.

20. Oueslati S, Hadj Fredj S, Siala H, Messaoud T. Study of the TGF beta1 codon 10 in cystic fibrosis tunisian patients. Clinical Chemistry and Laboratory Medicine 2015;53:S837.

21. Drumm ML, Konstan MW, Schluchter MD, Handler A, Pace R, Zou F, Zariwala M, Fargo D, Xu A, Dunn JM and others. Genetic modifiers of lung disease in cystic fibrosis. New England Journal of Medicine 2005;353(14):1443-1453.

22. Levy H, Linse G, Schneck K, Reske M, Kadunski M, Jia S, Lambert C, Hessner $M$. Integration of genomics with genetics-molecular phenotypes for cystic fibrosis (CF) lung disease. American Journal of Respiratory and Critical Care Medicine. Conference: American Thoracic Society International Conference, ATS 2010;181(1 MeetingAbstracts).

23. Arkwright PD, Pravica V, Geraghty PJ, Super M, Webb AK, Schwarz M, Hutchinson IV. End-organ dysfunction in cystic fibrosis: association with angiotensin I converting enzyme and cytokine gene polymorphisms. American Journal of Respiratory \& Critical Care Medicine 2003;167(3):384-9.

24. Dorfman R, Sandford A, Taylor C, Huang B, Frangolias D, Wang Y, Sang R, Pereira $L$, Sun $L$, Berthiaume $Y$ and others. Complex two-gene modulation of lung disease severity in children with cystic fibrosis. Journal of Clinical Investigation 2008;118(3):1040-9.

25. Faria EJ, Faria IC, Ribeiro JD, Ribeiro AF, Hessel G, Bertuzzo CS. Association of MBL2, TGF-beta1 and CD14 gene polymorphisms with lung disease severity in cystic fibrosis. Jornal Brasileiro De Pneumologia: Publicacao Oficial Da Sociedade Brasileira De Pneumologia E Tisilogia 2009;35(4):334-42.

26. Eickmeier O, Boom L, Schreiner F, Lentze MJ, D NG, Schubert R, Zielen S, Schmitt-Grohe $\mathrm{S}$. Transforming growth factor beta1 genotypes in relation to TGFbeta1, interleukin-8, and tumor necrosis factor alpha in induced sputum and blood in cystic fibrosis. Mediators of Inflammation 2013;2013:913135.

This article is protected by copyright. All rights reserved. 
27. Bremer LA, Blackman SM, Vanscoy LL, McDougal KE, Bowers A, Naughton KM, Cutler DJ, Cutting GR. Interaction between a novel TGFB1 haplotype and CFTR genotype is associated with improved lung function in cystic fibrosis. Human Molecular Genetics 2008;17(14):2228-37.

28. Collaco JM, Vanscoy L, Bremer L, McDougal K, Blackman SM, Bowers A, Naughton K, Jennings J, Ellen J, Cutting GR. Interactions between secondhand smoke and genes that affect cystic fibrosis lung disease. JAMA 2008;299(4):417-24.

29. Brazova J, Sismova K, Vavrova V, Bartosova J, Macek M, Jr., Lauschman H, Sediva A. Polymorphisms of TGF-beta1 in cystic fibrosis patients. Clinical Immunology 2006;121(3):350-7.

30. Corvol H, Boelle PY, Brouard J, Knauer N, Chadelat K, Henrion-Caude A, Flamant C, Muselet-Charlier C, Boule M, Fauroux B and others. Genetic variations in inflammatory mediators influence lung disease progression in cystic fibrosis. Pediatric Pulmonology 2008;43(12):1224-32.

31. Arkwright PD, Laurie S, Super M, Pravica V, Schwarz MJ, Webb AK, Hutchinson IV. TGF-beta(1) genotype and accelerated decline in lung function of patients with cystic fibrosis. Thorax 2000;55(6):459-62.

32. Buranawuti K, Boyle MP, Cheng S, Steiner LL, McDougal K, Fallin MD, Merlo C, Zeitlin PL, Rosenstein BJ, Mogayzel PJ. Variants in mannose-binding lectin and tumour necrosis factor $\alpha$ affect survival in cystic fibrosis. Journal of medical genetics 2007;44(3):209-214.

33. Dorfman R, Taylor C, Lin F, Sun L, Sandford A, Pare P, Berthiaume Y, Corey M, Durie $P$, Zielenski J. Modulatory effect of the SLC9A3 gene on susceptibility to infections and pulmonary function in children with cystic fibrosis. Pediatric Pulmonology 2011;46(4):385-392.

34. Magalhaes $M$, Rivals I, Claustres $M$, Varilh J, Thomasset $M$, Bergougnoux $A$, Mely L, Leroy S, Corvol $\mathrm{H}$, Guillot $\mathrm{L}$ and others. DNA methylation at modifier genes of lung disease severity is altered in cystic fibrosis. Clinical Epigenetics 2017;9 (1) (no pagination)(19).

35. Turner MW. The role of mannose-binding lectin in health and disease. Mol Immunol 2003;40(7):423-9.

36. Olesen HV, Jensenius JC, Steffensen R, Thiel S, Schiotz PO. The mannanbinding lectin pathway and lung disease in cystic fibrosis-dysfunction of mannan-binding lectin-associated serine protease 2 (MASP-2) may be a major modifier. Clinical Immunology 2006;121(3):324-331.

37. Yarden J, Radojkovic D, De Boeck K, Macek M, Jr., Zemkova D, Vavrova V, Vlietinck R, Cassiman JJ, Cuppens H. Polymorphisms in the mannose binding

This article is protected by copyright. All rights reserved. 
lectin gene affect the cystic fibrosis pulmonary phenotype. Journal of Medical Genetics 2004;41(8):629-33.

38. Gabolde M, Guilloud-Bataille M, Feingold J, Besmond C. Association of variant alleles of mannose binding lectin with severity of pulmonary disease in cystic fibrosis: cohort study. BMJ 1999;319(7218):1166-7.

39. Garred P, Pressler T, Madsen HO, Frederiksen B, Svejgaard A, Hoiby N, Schwartz $M$, Koch $C$. Association of mannose-binding lectin gene heterogeneity with severity of lung disease and survival in cystic fibrosis. Journal of Clinical Investigation 1999;104(4):431-7.

40. Gravina LP, Crespo C, Giugno H, Sen L, Chertkoff L, Mangano A, Castanos C. Mannose-binding lectin gene as a modifier of the cystic fibrosis phenotype in Argentinean pediatric patients. Journal of Cystic Fibrosis 2015;14(1):78-83.

41. Tarova ET, Polakova H, Kayserova H, Celec P, Zuzulova M, Kadasi L. Study of the effect of DNA polymorphisms in the mannose-binding lectin gene (MBL2) on disease severity in Slovak cystic fibrosis patients. General Physiology \& Biophysics 2011;30(4):373-8.

42. Davies JC, Turner MW, Klein N, Booth C, Johnson M, Shen N, Fidler K, Sharma $\mathrm{S}$, Burgess J, Bush A and others. Impaired pulmonary status in cystic fibrosis adults with two mutated MBL-2 alleles. European Respiratory Journal 2004;24(5):798-804.

43. Choi EH, Ehrmantraut M, Foster CB, Moss J, Chanock SJ. Association of common haplotypes of surfactant protein A1 and A2 (SFTPA1 and SFTPA2) genes with severity of lung disease in cystic fibrosis. Pediatric Pulmonology 2006;41(3):255-62.

44. Carlsson M, Sjoholm AG, Eriksson L, Thiel S, Jensenius JC, Segelmark M, Truedsson L. Deficiency of the mannan-binding lectin pathway of complement and poor outcome in cystic fibrosis: bacterial colonization may be decisive for a relationship. Clin Exp Immunol 2005;139(2):306-13.

45. Trevisiol C, Boniotto M, Giglio L, Poli F, Morgutti M, Crovella S. MBL2 polymorphisms screening in a regional Italian CF Center. Journal of Cystic Fibrosis 2005;4(3):189-191.

46. McDougal KE, Green DM, Vanscoy LL, Fallin MD, Grow M, Cheng S, Blackman SM, Collaco JM, Henderson LB, Naughton K. Use of a modeling framework to evaluate the effect of a modifier gene (MBL2) on variation in cystic fibrosis. European Journal of Human Genetics 2010;18(6):680-684.

47. Haerynck F, Van Steen K, Cattaert T, Loeys B, Schelstraete P, Claes K, Van Thielen M, De Canck I, John JM, De Baets F. Polymorphisms in the lectin pathway genes as a possible cause of early chronic Pseudomonas aeruginosa

This article is protected by copyright. All rights reserved. 
colonization in cystic fibrosis patients. Human immunology 2012;73(11):1175-1183.

48. Plant BJ, Gallagher CG, Bucala R, Baugh JA, Chappell S, Morgan L, O'Connor CM, Morgan K, Donnelly SC. Cystic fibrosis, disease severity, and a macrophage migration inhibitory factor polymorphism. American Journal of Respiratory \& Critical Care Medicine 2005;172(11):1412-5.

49. Adamali $\mathrm{H}$, Armstrong ME, McLaughlin AM, Cooke G, McKone E, Costello CM, Gallagher CG, Leng L, Baugh JA, Fingerle-Rowson G and others. Macrophage migration inhibitory factor enzymatic activity, lung inflammation, and cystic fibrosis. Am J Respir Crit Care Med 2012;186(2):162-9.

50. Melotti $P$, Mafficini $A$, Lebecque $P$, Ortombina $M$, Leal $T$, Pintani E, Pepermans X, Sorio C, Assael BM. Impact of MIF gene promoter polymorphism on F508del cystic fibrosis patients. PLOS ONE [Electronic Resource] 2014;9(12):e114274.

51. de Lima Marson FA, Bertuzzo CS, Secolin R, Ribeiro AF, Ribeiro JD. Genetic interaction of GSH metabolic pathway genes in cystic fibrosis. BMC Medical Genetics 2013;14:60.

52. Marson FA, Bertuzzo CS, Ribeiro AF, Ribeiro JD. Polymorphisms in the glutathione pathway modulate cystic fibrosis severity: a cross-sectional study. BMC Medical Genetics 2014;15:27.

53. Lima CS, Ortega MM, Marson FA, Zulli R, Ribeiro AF, Bertuzzo CS. Cystic fibrosis transmembrane conductance regulator gene mutations and glutathione S-transferase null genotypes in cystic fibrosis patients in Brazil. Jornal Brasileiro De Pneumologia: Publicacao Oficial Da Sociedade Brasileira De Pneumologia E Tisilogia 2012;38(1):50-6.

54. Hull J, Thomson AH. Contribution of genetic factors other than CFTR to disease severity in cystic fibrosis. Thorax 1998;53(12):1018-21.

55. Korytina G, laibaeva D, Viktorova T. Polymorphism of glutathione-Stransferase $\mathrm{M} 1$ and $\mathrm{P} 1$ genes in patients with cystic fibrosis and chronic respiratory tract diseases. Genetika 2004;40(3):401-408.

56. Feuillet-Fieux MN, Nguyen-Khoa T, Loriot MA, Kelly $M$, de Villartay $P$, Sermet I, Verrier P, Bonnefont JP, Beaune P, Lenoir $\mathrm{G}$ and others. Glutathione Stransferases related to $P$. aeruginosa lung infection in cystic fibrosis children: preliminary study. Clin Biochem 2009;42(1-2):57-63.

57. Flamant C, Henrion-Caude A, Boelle PY, Bremont F, Brouard J, Delaisi B, Duhamel JF, Marguet C, Roussey M, Miesch MC and others. Glutathione-Stransferase M1, M3, P1 and T1 polymorphisms and severity of lung disease in children with cystic fibrosis. Pharmacogenetics 2004;14(5):295-301.

This article is protected by copyright. All rights reserved. 
58. Haerynck F, Mahachie John JM, Van Steen K, Schelstraete $P$, Van daele $S$, Loeys B, Van Thielen M, De Canck I, Nuytinck L, De Baets F. Genetic variations in toll-like receptor pathway and lung function decline in Cystic fibrosis patients. Human Immunology 2013;74(12):1649-55.

59. Martin AC, Laing IA, Zhang G, Brennan S, Winfield K, Sly PD, Stick SM, Goldblatt J, LeSouef PN. CD14 C-159T and early infection with Pseudomonas aeruginosa in children with cystic fibrosis. Respir Res 2005;6:63.

60. Reid DW, Lam QT, Schneider H, Walters EH. Airway iron and iron-regulatory cytokines in cystic fibrosis. Eur Respir J 2004;24(2):286-91.

61. Stites SW, Plautz MW, Bailey K, O'Brien-Ladner AR, Wesselius LJ. Increased concentrations of iron and isoferritins in the lower respiratory tract of patients with stable cystic fibrosis. Am J Respir Crit Care Med 1999;160(3):796-801.

62. Smith D, Bell S, Anderson G, Reid D. HFE 282y mutations are associated with severity of lung disease and rate of lung function decline in cystic fibrosis. Respirology 2014;19:48.

63. Pratap U, Quinn S, Blizzard LB, Reid DW. Population-based study of cystic fibrosis disease severity and haemochromatosis gene mutations. Respirology 2010;15(1):141-9.

64. Darrah R, McKone E, O'Connor C, Rodgers C, Genatossio A, McNamara S, Gibson R, Elborn JS, Ennis M, Gallagher CG and others. EDNRA variants associate with smooth muscle mRNA levels, cell proliferation rates, and cystic fibrosis pulmonary disease severity. Physiological Genomics 2010;41(1):7177.

65. Becker T, Jansen S, Tamm S, Wienker TF, Tummler B, Stanke F. Transmission ratio distortion and maternal effects confound the analysis of modulators of cystic fibrosis disease severity on 19q13. European Journal of Human Genetics 2007;15(7):774-8.

66. Stanke F, Becker T, Hedtfeld S, Tamm S, Wienker TF, Tummler B. Hierarchical fine mapping of the cystic fibrosis modifier locus on 19q13 identifies an association with two elements near the genes CEACAM3 and CEACAM6. Human Genetics 2010;127(4):383-94.

67. Corvol H, Blackman SM, Boelle PY, Gallins PJ, Pace RG, Stonebraker JR, Accurso FJ, Clement A, Collaco JM, Dang $\mathrm{H}$ and others. Genome-wide association meta-analysis identifies five modifier loci of lung disease severity in cystic fibrosis. Nature Communications 2015;6 (no pagination)(8382).

68. Guo X, Pace RG, Stonebraker JR, Commander CW, Dang AT, Drumm ML, Harris A, Zou F, Swallow DM, Wright FA and others. Mucin variable number tandem repeat polymorphisms and severity of cystic fibrosis lung disease:

This article is protected by copyright. All rights reserved. 
significant association with MUC5AC. PLoS ONE [Electronic Resource] 2011;6(10):e25452.

69. Mekus F, Laabs U, Veeze H, Tummler B. Genes in the vicinity of CFTR modulate the cystic fibrosis phenotype in highly concordant or discordant F508del homozygous sib pairs. Human Genetics 2003;112(1):1-11.

70. Stanke F, Davenport C, Hedtfeld S, Tummler B. Differential decay of parentof-origin-specific genomic sharing in cystic fibrosis-affected sib pairs maps a paternally imprinted locus to 7q34. European Journal of Human Genetics 2010;18(5):553-9.

71. Emond MJ, Louie T, Emerson J, Chong JX, Mathias RA, Knowles MR, Rieder MJ, Tabor HK, Nickerson DA, Barnes KC and others. Exome Sequencing of Phenotypic Extremes Identifies CAV2 and TMC6 as Interacting Modifiers of Chronic Pseudomonas aeruginosa Infection in Cystic Fibrosis. PLoS Genetics 2015;11 (6) (no pagination)(e1005273).

72. Emond MJ, Louie T, Emerson J, Zhao W, Mathias RA, Knowles MR, Wright FA, Rieder MJ, Tabor HK, Nickerson DA and others. Exome sequencing of extreme phenotypes identifies DCTN4 as a modifier of chronic Pseudomonas aeruginosa infection in cystic fibrosis. Nature Genetics 2012;44(8):886-9.

73. Viel M, Hubert D, Burgel PR, Genin E, Honore I, Martinez B, Gaitch N, Chapron J, Kanaan R, Dusser D and others. DCTN4 as a modifier of chronic Pseudomonas aeruginosa infection in cystic fibrosis. The clinical respiratory journal 2016;10(6):777-783.

74. Wright FA, Strug LJ, Doshi VK, Commander CW, Blackman SM, Sun L, Berthiaume Y, Cutler D, Cojocaru A, Collaco JM and others. Genome-wide association and linkage identify modifier loci of lung disease severity in cystic fibrosis at 11p13 and 20q13.2. Nature Genetics 2011;43(6):539-546.

75. Gu Y, Harley IT, Henderson LB, Aronow BJ, Vietor I, Huber LA, Harley JB, Kilpatrick JR, Langefeld CD, Williams AH and others. Identification of IFRD1 as a modifier gene for cystic fibrosis lung disease. Nature 2009;458(7241):103942.

76. Li W, Soave D, Miller MR, Keenan K, Lin F, Gong J, Chiang T, Stephenson AL, Durie $\mathrm{P}$, Rommens $\mathrm{J}$ and others. Unraveling the complex genetic model for cystic fibrosis: pleiotropic effects of modifier genes on early cystic fibrosisrelated morbidities. Human Genetics 2014;133(2):151-61.

77. Soave D, Corvol H, Panjwani N, Gong J, Li W, Boelle PY, Durie PR, Paterson $A D$, Rommens JM, Strug $\amalg$ and others. A Joint Location-Scale Test Improves Power to Detect Associated SNPs, Gene Sets, and Pathways. American Journal of Human Genetics 2015;97(1):125-138.

This article is protected by copyright. All rights reserved. 
78. Aron Y, Polla BS, Bienvenu T, Dall'ava J, Dusser D, Hubert D. HLA class II polymorphism in cystic fibrosis. A possible modifier of pulmonary phenotype. American Journal of Respiratory \& Critical Care Medicine 1999;159(5 Pt 1):1464-8.

79. O'Neal WK, Gallins P, Pace RG, Dang H, Wolf WE, Jones LC, Guo X, Zhou YH, Madar $V$, Huang $J$ and others. Gene expression in transformed lymphocytes reveals variation in endomembrane and HLA pathways modifying cystic fibrosis pulmonary phenotypes. American Journal of Human Genetics 2015;96(2):318-28.

80. Dang H, Gallins PJ, Pace RG, Guo XL, Stonebraker JR, Corvol H, Cutting GR, Drumm ML, Strug LJ, Knowles MR and others. Novel variation at chr11p13 associated with cystic fibrosis lung disease severity. Human Genome Variation 2016;3 (no pagination)(201620).

81. Feinberg AP. The Key Role of Epigenetics in Human Disease Prevention and Mitigation. N Engl J Med 2018;378(14):1323-1334.

82. Ideozu JE, Zhang X, Pan A, Ashrafi Z, Woods KJ, Hessner MJ, Simpson P, Levy $\mathrm{H}$. Increased Expression of Plasma-Induced ABCC1 mRNA in Cystic Fibrosis. Int J Mol Sci 2017;18(8).

83. Hurbain I, Sermet-Gaudelus I, Vallee B, Feuillet MN, Lenoir G, Bernaudin JF, Edelman A, Fajac A. Evaluation of MRP1-5 gene expression in cystic fibrosis patients homozygous for the delta F508 mutation. Pediatr Res 2003;54(5):627-34.

84. Kelly C, Williams MT, Elborn JS, Ennis M, Schock BC. Expression of the inflammatory regulator $A 20$ correlates with lung function in patients with cystic fibrosis. Journal of Cystic Fibrosis 2013;12(4):411-5.

85. Wright JM, Merlo CA, Reynolds JB, Zeitlin PL, Garcia JG, Guggino WB, Boyle MP. Respiratory epithelial gene expression in patients with mild and severe cystic fibrosis lung disease. American Journal of Respiratory Cell \& Molecular Biology 2006;35(3):327-36.

86. Amaral MD, Balch WE. Hallmarks of therapeutic management of the cystic fibrosis functional landscape. J Cyst Fibros 2015;14(6):687-99.

87. Hart MA, Konstan MW, Darrah RJ, Schluchter MD, Storfer-Isser A, Xue L, Londono D, Goddard KA, Drumm ML. Beta 2 adrenergic receptor polymorphisms in cystic fibrosis. Pediatric Pulmonology 2005;39(6):544-50.

88. Marson FA, Bertuzzo CS, Ribeiro AF, Ribeiro JD. Polymorphisms in ADRB2 gene can modulate the response to bronchodilators and the severity of cystic fibrosis. BMC Pulmonary Medicine 2012;12:50.

This article is protected by copyright. All rights reserved. 
89. Steagall WK, Barrow BJ, Glasgow CG, Mendoza JW, Ehrmantraut M, Lin JP, Insel PA, Moss J. Beta-2-adrenergic receptor polymorphisms in cystic fibrosis. Pharmacogenetics and Genomics 2007;17(6):425-30.

90. Buscher R, Eilmes KJ, Grasemann H, Torres B, Knauer N, Sroka K, Insel PA, Ratjen $\mathrm{F}$. beta2 adrenoceptor gene polymorphisms in cystic fibrosis lung disease. Pharmacogenetics 2002;12(5):347-53.

91. Strug LJ, Gonska T, He G, Keenan K, Ip W, Boelle PY, Lin F, Panjwani N, Gong J, Li W and others. Cystic fibrosis gene modifier SLC26A9 modulates airway response to CFTR-directed therapeutics. Human Molecular Genetics 2016;25(20):4590-4600.

92. Pittman JE, Cutting G, Davis SD, Ferkol T, Boucher R. Cystic fibrosis: NHLBI Workshop on the Primary Prevention of Chronic Lung Diseases. Ann Am Thorac Soc 2014;11 Suppl 3:S161-8.

93. von Kanel T, Stanke F, Weber M, Schaller A, Racine J, Kraemer R, Chanson M, Tummler B, Gallati S. Clinical and molecular characterization of the potential CF disease modifier syntaxin 1A. European Journal of Human Genetics 2013;21(12):1462-6.

94. Gisler FM, von Kanel T, Kraemer R, Schaller A, Gallati S. Identification of SNPs in the cystic fibrosis interactome influencing pulmonary progression in cystic fibrosis. European Journal of Human Genetics 2013;21(4):397-403.

95. Horsley AR, Gustafsson PM, Macleod KA, Saunders C, Greening AP, Porteous DJ, Davies JC, Cunningham S, Alton EW, Innes JA. Lung clearance index is a sensitive, repeatable and practical measure of airways disease in adults with cystic fibrosis. Thorax 2008;63(2):135-40.

96. Gustafsson PM, De Jong PA, Tiddens HA, Lindblad A. Multiple-breath inert gas washout and spirometry versus structural lung disease in cystic fibrosis. Thorax 2008;63(2):129-34.

97. Aurora P, Bush A, Gustafsson P, Oliver C, Wallis C, Price J, Stroobant J, Carr S, Stocks J. Multiple-breath washout as a marker of lung disease in preschool children with cystic fibrosis. Am J Respir Crit Care Med 2005;171(3):249-56.

98. Rosenfeld M, Emerson J, Accurso F, Armstrong D, Castile R, Grimwood K, Hiatt P, McCoy K, McNamara S, Ramsey B and others. Diagnostic accuracy of oropharyngeal cultures in infants and young children with cystic fibrosis. Pediatr Pulmonol 1999;28(5):321-8.

99. Hall GL, Logie KM, Parsons F, Schulzke SM, Nolan G, Murray C, Ranganathan $S$, Robinson $P$, Sly PD, Stick SM and others. Air trapping on chest $C T$ is associated with worse ventilation distribution in infants with cystic fibrosis diagnosed following newborn screening. PLoS One 2011;6(8):e23932.

This article is protected by copyright. All rights reserved. 
100. Ramsey KA, Rosenow T, Turkovic L, Skoric B, Banton G, Adams AM, Simpson SJ, Murray C, Ranganathan SC, Stick SM and others. Lung Clearance Index and Structural Lung Disease on Computed Tomography in Early Cystic Fibrosis. Am J Respir Crit Care Med 2016;193(1):60-7.

101. Darrah RJ, Jacono FJ, Joshi N, Mitchell AL, Sattar A, Campanaro CK, Litman P, Frey J, Nethery DE, Barbato ES and others. AGTR2 absence or antagonism prevents cystic fibrosis pulmonary manifestations. J Cyst Fibros 2018.

102. Tung NM, Garber JE. BRCA1/2 testing: therapeutic implications for breast cancer management. British Journal of Cancer 2018;119(2):141-152.

103. Corvol H, Mesinele J, Douksieh IH, Strug LJ, Boelle PY, Guillot L. SLC26A9 Gene Is Associated With Lung Function Response to Ivacaftor in Patients With Cystic Fibrosis. Front Pharmacol 2018;9:828.

104. Liberati A, Altman DG, Tetzlaff J, Mulrow C, Gotzsche PC, loannidis JP, Clarke $M$, Devereaux PJ, Kleijnen J, Moher D. The PRISMA statement for reporting systematic reviews and meta-analyses of studies that evaluate health care interventions: explanation and elaboration. PLoS Med 2009;6.

105. Polineni D, Dang H, Gallins PJ, Jones LC, Pace RG, Stonebraker JR, Commander LA, Krenicky JE, Zhou YH, Corvol H and others. Airway Mucosal Host Defense Is Key to Genomic Regulation of Cystic Fibrosis Lung Disease Severity. Am J Respir Crit Care Med 2018;197(1):79-93.

106. Smith DJ, Klein K, Hartel G, Wainwright CE, Bell SC, Anderson GJ, Reid DW. Mutations in the HFE gene can be associated with increased lung disease severity in cystic fibrosis. Gene 2019;683:12-17.

107. Sly PD, Gangell CL, Chen L, Ware RS, Ranganathan S, Mott LS, Murray CP, Stick SM. Risk factors for bronchiectasis in children with cystic fibrosis. N Engl J Med 2013;368(21):1963-70.

108. Eckford PDW, McCormack J, Munsie L, He G, Stanojevic S, Pereira SL, Ho K, Avolio J, Bartlett C, Yang JY and others. The CF Canada-Sick Kids Program in individual CF therapy: A resource for the advancement of personalized medicine in CF. J Cyst Fibros 2018.

This article is protected by copyright. All rights reserved. 
Table 1. Benefits of accurate prediction of lung disease severity in CF

\begin{tabular}{|c|c|c|}
\hline Group & $\begin{array}{l}\text { Benefits of Identifying Risk } \\
\text { of Significant Disease }\end{array}$ & $\begin{array}{l}\text { Benefits of Identifying Mild } \\
\text { Disease }\end{array}$ \\
\hline Patient/Family & $\begin{array}{l}\text { - Better understanding of } \\
\text { likely disease course } \\
\text { - Understand necessity of } \\
\text { burden of care } \\
\text { - Better informed decisions } \\
\text { about family planning }\end{array}$ & $\begin{array}{l}\text { - Reduced burden of care } \\
\text { with resultant improved } \\
\text { quality of life } \\
\text { - Reduced exposure to } \\
\text { iatrogenic risks } \\
\text { - Better informed decisions } \\
\text { about family planning }\end{array}$ \\
\hline $\begin{array}{l}\text { CF Health Care } \\
\text { Team }\end{array}$ & $\begin{array}{l}\text { - Inform implementation of } \\
\text { earlier/more aggressive } \\
\text { treatments } \\
\text { - Increased monitoring/ } \\
\text { surveillance }\end{array}$ & $\begin{array}{l}\text { - Reduced burden of care } \\
\text { - Less frequent monitoring, } \\
\text { thus improving patient quality } \\
\text { of life and allowing CF team } \\
\text { to concentrate resources } \\
\text { elsewhere }\end{array}$ \\
\hline Health Authorities & $\begin{array}{l}\text { - Allocate resources (new } \\
\text { treatments, more carers) to } \\
\text { patients most likely to }\end{array}$ & $\begin{array}{l}\text { - Avoid allocation of } \\
\text { resources to patient whose } \\
\text { disease trajectory is unlikely }\end{array}$ \\
\hline
\end{tabular}

This article is protected by copyright. All rights reserved. 


\begin{tabular}{|l|l|l|}
\hline Researchers & benefit & to be altered \\
\hline to benefit from new & interventions & therapeutic targets \\
& $\begin{array}{l}\text { - Potentially identify new } \\
\text { therapeutic targets }\end{array}$ & - Explanation of \\
& heterogeneous response to \\
- Explanation of & new treatments \\
heterogeneous response to & \\
\hline
\end{tabular}

Table 2. Inclusion/Exclusion Criteria

\begin{tabular}{|c|c|}
\hline Inclusion & Exclusion \\
\hline $\begin{array}{l}\text { - } \text { Human Studies } \\
\text { - } \text { Patients with Cystic Fibrosis } \\
\text { expression, or regulation studied } \\
\text { - Measure of lung disease severity as } \\
\text { outcome (lung function, lung } \\
\text { structure, microbiology, composite }\end{array}$ & $\begin{array}{l}\text { - Animal Studies } \\
\text { - Patients with other medical } \\
\text { conditions } \\
\text { - Studies involving CFTR gene only } \\
\text { - } \text { Re measure of lung disease severity }\end{array}$ \\
\hline
\end{tabular}

This article is protected by copyright. All rights reserved. 
score, etc.)

- Original data

Table 3. Summary of Investigated Genes by Result

\begin{tabular}{|c|c|c|c|c|}
\hline $\begin{array}{l}\text { Hypothesised } \\
\text { Mechanism }\end{array}$ & No Effect & $\begin{array}{l}\text { Conflicting } \\
\text { Results }\end{array}$ & $\begin{array}{l}\text { Effect shown with } \\
\text { no attempt at } \\
\text { replication }\end{array}$ & $\begin{array}{l}\text { Multiple } \\
\text { Studies } \\
\text { showing } \\
\text { effect with no } \\
\text { conflicting } \\
\text { result }\end{array}$ \\
\hline $\begin{array}{l}\text { Alternate Ion } \\
\text { Channel }\end{array}$ & $\begin{array}{l}C L C-2, \\
S C N N 1 A \\
N E D D 4 L\end{array}$ & $\begin{array}{l}\text { SCNN1 } \\
\text { SCNN1ß, } \\
\text { SLC26A9 }\end{array}$ & & \\
\hline $\begin{array}{l}\text { Located within loci } \\
\text { identified via } \\
\text { Genome Wide } \\
\text { Search }\end{array}$ & & & $\begin{array}{l}\text { ATF1, DUOX2, } \\
\text { YY1, AGTR2, } \\
\text { CAV2, LPAR6, } \\
\text { SLC9A3R2, TMC6, } \\
\text { APIP, EHF, EZR }\end{array}$ & $\begin{array}{l}\text { SLC9A3, } \\
\text { HLA-CLASS } \\
\text { II, DCTN4, } \\
\text { SLC6A14 }\end{array}$ \\
\hline Bronchoconstriction & & $A D R B 2$ & & EDNRA \\
\hline CFTR Interaction & $\begin{array}{l}\text { AnxA5, } \\
\text { PPP2R5E, } \\
\text { AHSA1, CALR, } \\
\text { KRT18, PRSS8, } \\
\text { ABCC2-5, }\end{array}$ & $A B C C 1$, & $\begin{array}{l}\text { PPP2R1A, } \\
\text { PPP2R4, STX1A, } \\
\text { SNAP23, KRT8, } \\
\text { KRT19 }\end{array}$ & \\
\hline $\begin{array}{l}\text { CFTR Vicinity or } \\
\text { Haplotype }\end{array}$ & $\begin{array}{l}\text { D7S495, } \\
\text { D7S525, } \\
\text { D7S514, XV2C, } \\
\text { Tub20, MetH, } \\
\text { kM.19, J3.11 }\end{array}$ & MP6d9 & LEP1, LEP2, & \\
\hline
\end{tabular}

This article is protected by copyright. All rights reserved. 


\begin{tabular}{|c|c|c|c|c|}
\hline $\begin{array}{l}\text { Infection } \\
\text { Susceptibility }\end{array}$ & $\begin{array}{l}\text { MASP-2, ABO, } \\
\text { CHIT1, DEFß4, } \\
\text { FUT2, FUT3, } \\
\text { Haptoglobin, } \\
\text { MASP-1, T2R38 }\end{array}$ & $\begin{array}{l}\text { DEFß1, } \\
C D 14, C F \beta\end{array}$ & $\begin{array}{l}\text { C3, CXCR1, } \\
\text { CXCR2, FAS, } \\
\text { FCN1, FCN2, } \\
\text { MASP-3, CHIT3- } \\
\text { Like 1 }\end{array}$ & $\begin{array}{l}\text { CEACAM, } \\
\text { HFE, } \\
\text { HMOX1, }\end{array}$ \\
\hline $\begin{array}{l}\text { Infection } \\
\text { Susceptibility and } \\
\text { Inflammatory } \\
\text { Response; }\end{array}$ & $\begin{array}{l}\text { LBP, TLR3, } \\
\text { TLR6, TLR7, } \\
\text { TLR8, TLR9, } \\
\text { TLR10, IL-1A, } \\
\text { IL-1R1, TLR4 }\end{array}$ & $\begin{array}{l}M B L, T L R 5, \\
I L-1 \beta, I L-1 R N\end{array}$ & $T L R 1, T L R 2$ & \\
\hline Nitric Oxide & & $\begin{array}{l}\text { NOS-1, NOS- } \\
3\end{array}$ & & \\
\hline $\begin{array}{l}\text { Inflammatory } \\
\text { Response }\end{array}$ & $\begin{array}{l}I F N \gamma, I L-6, \\
\text { STAT3, } \\
\text { TAX1BP1, }\end{array}$ & $\begin{array}{l}\text { TNF } \alpha, \alpha-1- \\
\text { antitrypsin, } \\
\text { ACE, IL-10, } \\
\text { IFRD1, IL-8, } \\
\text { COX2, LT- } \\
\text { alpha, AGER- } \\
\text { 429, HSP70- } \\
2 G \text {, }\end{array}$ & 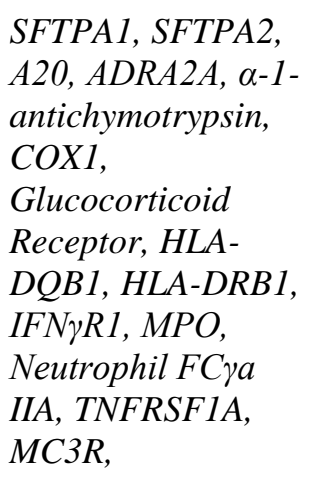 & $T G F \beta 1, M I F$ \\
\hline Mucin & MUC2, MUC7 & & $\begin{array}{l}\text { MUC5AC, MUC1, } \\
M U C 4, M U C 20\end{array}$ & \\
\hline $\begin{array}{l}\text { Oxidative Lung } \\
\text { Injury }\end{array}$ & & $\begin{array}{l}\text { GSTM1, } \\
\text { GSTP1, } \\
\text { GSTT1, }\end{array}$ & $m E P H X$ & $\begin{array}{l}\text { GCLC, } \\
\text { GSTM3, }\end{array}$ \\
\hline
\end{tabular}

This article is protected by copyright. All rights reserved. 


\section{Figure}

PRISMA Flowchart for Study Selection

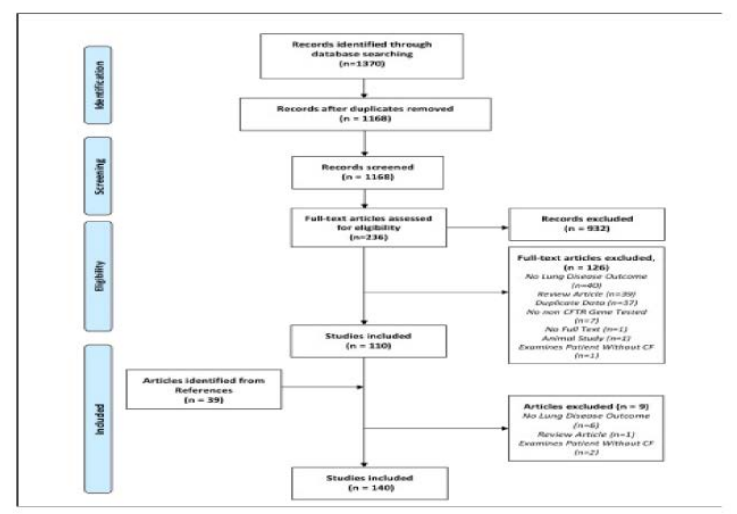

This article is protected by copyright. All rights reserved. 


\section{University Library}

\section{- M M N E R VA A gateway to Melbourne's research publications}

Minerva Access is the Institutional Repository of The University of Melbourne

Author/s:

Shanthikumar, S;Neeland, MN;Saffery, R;Ranganathan, S

Title:

Gene modifiers of cystic fibrosis lung disease: A systematic review

Date:

2019-09-01

Citation:

Shanthikumar, S., Neeland, M. N., Saffery, R. \& Ranganathan, S. (2019). Gene modifiers of cystic fibrosis lung disease: A systematic review. PEDIATRIC PULMONOLOGY, 54 (9), pp.1356-1366. https://doi.org/10.1002/ppul.24366.

Persistent Link:

http://hdl.handle.net/11343/285917 